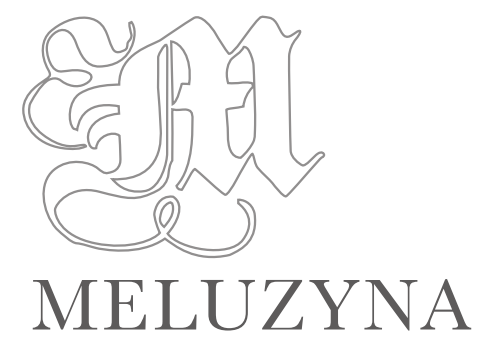

ISSN 2449-7339

2 (5) (2016) I Rocznik III

DOI: 10.18276/me.2016.2-04

KONTEKSTY I NAWIAZZANIA

\author{
Dominik Sobczyk \\ Uniwersytet Wrocławski
}

\title{
Arnoszt z Pardubic w pamięci lokalnej Kłodzka
}

Badania nad zagadnieniem szeroko pojętej pamięci zapoczątkowane zostały w pierwszej połowie XX wieku, głównie przez socjologów i historyków. Obecna dziś interdyscyplinarność i komplementarność w humanistyce sprawiły jednak, że teorią pamięci zajmują się też przedstawiciele innych dziedzin: antropologowie, filozofowie, kulturoznawcy, literaturoznawcy i politolodzy. Być może z tego rozszerzenia na wiele dyscyplin (wszak inne czynniki też należy brać pod uwagę $\left.{ }^{2}\right) \mathrm{w}$ studiach nad pamięcią wynika prawdziwa erupcja prac poświęconych tej problematyce, którą można zaobserwować na polskim rynku wydawniczym³ ${ }^{3}$ Wyraźnie wzmożone zainteresowanie zróżnicowanych środowisk naukowych badaniami nad teorią pamięci jest z pewnością korzystne dla tego zagadnienia. Nie ulega jednak wątpliwości, że interdyscyplinarny i wieloznaczny charakter tych studiów doprowadził do powstania pewnego chaosu natury terminologicznej. Badacze, pisząc o tym samym zjawisku, często używają zamiennie takich pojęć, jak: „pamięć społeczna”, „pamięć zbiorowa”, „pamięć historyczna”, „pamięć kulturowa”, „pamięć komunikacyjna” (Poczykowski, 2010, s. 26). Podobnie rzecz ma się z kategoriami (a może „wymiarami”, idąc za tytułem książki Radosława Poczykowskiego?) pamięci (ich wyodrębnienie jest najpewniej efektem wspomnianej interdyscyplinarności w podejściu do tych badań). W literaturze wielokrotnie można spotkać się np. z zamiennym stosowaniem terminów „pamięć lokalna” i „pamięć regionalna”. Ów problem zasygnalizowali autorzy swoistej encyklopedii Modi

\footnotetext{
e-mail autora: kovalf1@wp.pl

1 W polskiej nauce za inicjującą wzmożone zainteresowanie problematyką pamięci uważa się pracę francuskiego socjologa Maurice'a Halbwachsa (Halbwachs, 2008).

2 Jest nią transformacja ustrojowa w Polsce w roku 1989. Za jej sprawą nauki humanistyczne wydostały się spod ucisku polityki i ideologii, otwierając się na nowe, demokratyczne metody i nurty, na co zwrócił uwagę np. Nahirny, 2010, s. 140.

3 Zob. m.in. Szpociński, 2005; Le Goff, 2007; Connerton, 2012; Assmann, 2013; Saryusz-Wolska, Traba, 2014.
} 
memorandi. Leksykon kultury i pamięci (Saryusz-Wolska, Traba, 2014), świeżej i monumentalnej pracy poświęconej szeroko rozumianej pamięci w ujęciu terminologicznym. Warto pokazać, w jaki sposób uczeni odpowiedzialni za kształt powyższego opracowania zdefiniowali pamięć lokalną:

[...] pamięć związana z określonymi grupami ludzi na wyodrębnionym terytorium. [...] W literaturze przedmiotu terminy "pamięć lokalna « $\mathrm{i}$ "pamięć regionalna « bywają używane zamiennie, analogicznie do historii lokalnej i regionalnej. [...] Wspólnym mianownikiem dla wszelkich aspektów pamięci lokalnej jest jej występowanie na określonym terytorium i ścisły związek z tożsamością lokalną (Woniak, 2014, s. 339-440).

Nieco odmienne podejście zaprezentował Poczykowski, który pisał:

Nie wszystkie wspólnoty pamięci powiązane są z określonym terytorium, wystarczy przywołać wspólnoty wirtualne, czy pokoleniowe, które łączy wspólnota losów, czy pamięć wydarzenia, ale nie miejsce. Wspólnoty lokalne są niejako z definicji terytorialne, traktujące pewien, zwykle niewielki obszar jako »małą ojczyznę«. Przy czym obszar ten nie musi być przez tę zbiorowość faktycznie obecnie zamieszkiwany, a wspólnota, może być rozproszona po świecie. [...] Pamięć lokalna jest więc pamięcią nawiązującą emocjonalnie do terytorium rozpoznawanego jako ojczyzna (Poczykowski, 2010, s. 90-91).

Koncepcja Poczykowskiego może posłużyć jako uzupełnienie definicji zaczerpniętej z leksykonu. W istocie pamięć lokalna dotyczy tych zdarzeń i symboli, które pewna społeczność, nie tylko terytorialna, czyli zamieszkująca konkretne miasto, wieś czy dzielnicę, ale też „rozproszona po świecie”, uznaje za element swej tożsamości regionalnej.

Autorzy leksykonu w haśle „pamięć lokalna” poruszają (w obrębie tego zagadnienia) kwestię postaci. Według uczonych specyfika pamięci lokalnej polega m.in. na tym, że w jej centrum uwagi znajdują się, poza wspólnotami, również wybrane jednostki (Woniak, 2014, s. 339). Wydaje się jednak, że rola postaci wcale nie jest elementem odróżniającym pamięć lokalną od innych pamięci, lecz cechą uniwersalną, równie ważną w innych kategoriach pamięci.

Kolejnym interesującym ogniwem w definiowaniu pamięci lokalnej w leksykonie jest wzmianka o sposobach jej pielęgnowania. Okazuje się, że o historię „małej ojczyzny” można dbać w wieloraki sposób, m.in. poprzez upamiętnianie w ramach instytucji (w lokalnych muzeach, archiwach, szkołach, kościołach), inicjatywy społeczeństwa obywatelskiego (działalność na polu samorządowym) oraz zaangażowanie pojedynczych osób (historyków, amatorów, animatorów życia kulturalnego, nauczycieli, artystów). Zaprezentowane działania powinny być dostrzegalne w nazewnictwie ulic, funkcjonowaniu regionalnych mitów i tradycji, uroczystościach i lokalnej historiografii (Woniak, 2014, s. 340).

Wymienione zagadnienia, czyli problem jednostki oraz formy upamiętniania historii „małej ojczyzny" wobec pamięci lokalnej, staną się tematem niniejszego artykułu. Zaprezentowane bowiem zostaną koncepcje pielęgnowania pamięci przez dawną i obecną społeczność Kłodzka o Arnoszcie z Pardubic - pierwszym arcybiskupie praskim, jednym z najważniejszych bohaterów historycznych największego ośrodka Ziemi Kłodzkiej. 
Arnoszt z Pardubic przyszedł na świat w 1297 roku najprawdopodobniej w Hostince (Szczepaniak, 2004, s. 8), choć nie brak podstaw do wysunięcia hipotezy, że miejscem narodzin przyszłego dostojnika kościelnego mogło być Kłodzko. Według Anny Pobóg-Lenartowicz Arnoszt całe swoje dzieciństwo spędził bowiem w Kłodzku (Pobóg-Lenartowicz, 1999, s. 214). Pogląd uczonej wyniknął zapewne z faktu sprawowania przez ojca pierwszego arcybiskupa Pragi, rycerza Arnoszta z Hostinki, funkcji urzędnika króla czeskiego w mieście na początku XIV stulecia (Wilhelm z Lestkowa, 2004, s. 13). W tym czasie młody Arnoszt uczęszczał do kłodzkiej szkoły prowadzonej przez joannitów. Chłopiec, jako podopieczny miejscowych szpitalników, niejednokrotnie przebywał w ich kościele parafialnym. W trakcie jednego z nabożeństw przytrafiło mu się wstrząsające, mistyczne przeżycie. Czuwając w modlitwie, spojrzał na wizerunek Matki Bożej, umiejscowiony nad głównym ołtarzem. Madonna gwałtownie odwróciła się od chłopca, po czym ze zwłoką zwróciła na niego ponownie swe oblicze, okazując łaskę. Szerszy opis powyższej wizji sporządził u schyłku życia sam Arnoszt z Pardubic (Wilhelm z Lestkowa, 2004, s. 21). Miraculum spowodowało przemianę moralną młodzieńca - stał się odtąd wielkim admiratorem Matki Boskiej oraz podjął decyzję o zostaniu duchownym. Kariera kościelna Arnoszta rozwinęła się pomyślnie (kilkanaście lat spędził na studiach w Italii). Piastował m.in. godność kanonika praskiego oraz wrocławskiego. Zwieńczeniem jego długoletniej służby Kościołowi miała być nominacja na stanowisko biskupa praskiego, którą otrzymał z rąk papieża Klemensa VI w 1343 roku, tuż po śmierci dotychczasowego ordynariusza Jana z Drażyc. Przeszło rok później Arnoszt z Pardubic był już jednak pierwszym w historii arcybiskupem praskim - decyzją wspomnianego wyżej papieża diecezję tę wyniesiono do rangi archidiecezji. Był to niewątpliwy sukces dyplomacji Luksemburgów - króla czeskiego Jana oraz jego syna i następcy, późniejszego cesarza Karola IV. Arnoszt na dworze tego ostatniego pełnił ważną rolę, mianowicie był jego osobistym doradcą i wiernym przyjacielem.

Objęcie stolca arcybiskupiego w Pradze zbiegło się z bodaj pierwszym wielkim przedsięwzięciem fundacyjnym Arnoszta w Kłodzku. Miasto, chociaż dotknięte przeróżnymi katastrofami i nieszczęściami w początkach wieku XIV (Mrozowicz, 2000, s. 209-226), stanęło na nogi i około połowy tegoż stulecia rozwinęło się pod wieloma względami (Dziewulski, 1957, s. 447-485). Arnoszt przyczynił się do rozwoju Kłodzka w sferze architektonicznej. Wychowanek miejscowych joannitów nie zapomniał o swoich nauczycielach - w 1344 roku, z inicjatywy arcybiskupa, kłodzcy szpitalnicy położyli kamień węgielny pod budowę nowego kościoła parafialnego. Sternik archidiecezji praskiej miał zapisać w testamencie na ten cel poważne sumy (Broniewski, 1970, s. 40). Proces wznoszenia świątyni zakończył się w latach 1552-1555.

Kolejna inwestycja, również wiążąca się z koniecznością budowania nowych gmachów, dotyczyła innego zgromadzenia zakonnego. Tym razem Arnoszt z Pardubic, w ramach odnowy kanonikatu, w 1349 roku założył klasztor kanoników regularnych św. Augustyna. Pierwsi zakonnicy przybyli do Kłodzka z Rudnic nad Łabą, gdzie znajdował się klasztor-macierz, powołany do życia kilkanaście lat wcześniej przez Jana z Drażyc (Orłowski, 2005, s. 195). Poprzedni biskup praski był wielkim zwolennikiem kanoników regularnych i afirmowanego przez nich ruchu devotio moderna, który zakładał gruntowną reformę życia moralnego kleru w oparciu o odnowę ducha religijnego. Szczególnie ważną rolę odgrywały takie cnoty jak ubóstwo, czystość, praca. Nurt devotio moderna, zyskujący w Czechach na znaczeniu w XIV wieku, przypadł do gustu Ar- 
nosztowi z Pardubic. Zapewne stąd wzięła się jego sympatia do kanoników regularnych św. Augustyna, wówczas głównych propagatorów tej idei w Europie Środkowo-Wschodniej.

Kłodzcy kanonicy regularni zostali solidnie uposażeni przez metropolitę praskiego. Na ich siedzibę wybrano południowo-zachodni stok Góry Zamkowej, na którym stanął klasztor oraz kościół tumski Zwiastowania Najświętszej Marii Panny. Ponadto zakonnicy otrzymali rozległe grunty na terenie czterech wsi sąsiadujących z Kłodzkiem, które Arnoszt nabył wcześniej, wraz z braćmi, od miejscowego zamożnego rodu (Korta, 1983, nr 245). Nadania ziemskie niewątpliwie znacznie poprawiły sytuację ekonomiczną kanoników regularnych, co umożliwiło z czasem rozpoczęcie intensywnej działalności intelektualnej.

Prepozytura stała się ważnym centrum życia umysłowego w Kłodzku, a to za sprawą m.in. cennych darowizn książkowych Arnoszta z Pardubic, stanowiących zręby biblioteki klasztornej. Księgozbiór ojców nie przetrwał jednak, ulegając zniszczeniu w czasie wojny trzydziestoletniej. Ponadto kanonia cieszyła się własnym skryptorium, w którym podobno miała zostać sporządzona pierwsza część jednego z najstarszych zabytków języka polskiego - Psałterza Floriańskiego, przeznaczonego dla królowej Jadwigi Andegaweńskiej (Gębarowicz, 1965; zob. też Matusik, 1965, s. 277-317; Łatak, 1999, s. 58-59).

Patronat arcybiskupa Arnoszta z Pardubic umożliwił kłodzkim kanonikom regularnym św. Augustyna osiągnięcie wysokiego poziomu życia materialnego i duchowego. Najprawdopodobniej jednak czeski dostojnik kościelny nie uprawnił ojców do prowadzenia jakiejkolwiek działalności edukacyjnej, o czym świadczy konflikt, do którego doszło pomiędzy joannitami a kanonikami regularnymi. Organizacją życia szkolnego w Kłodzku od jakiegoś czasu zajmowali się właśnie szpitalnicy. Mieli oni założyć pierwszą szkołę w XIII wieku, choć najstarsza wzmianka o jej istnieniu pochodzi z około 1310 roku, kiedy nauki pobierał tu Arnoszt z Pardubic (Staffa, 1994, s. 199). Placówka, znajdująca się przy kościele farnym, miała charakter szkoły parafialnej, w której uczono łaciny, pisania, liczenia i śpiewu (Szczepaniak, 2005, s. 9). Zdaje się, że przybyli do Kłodzka kanonicy regularni wnet zapragnęli powołać do życia własną szkołę, co doprowadziło do zatargu z joannitami (Mrozowicz, 1995, s. 63-81). Dla złagodzenia sporu interweniować musiał Arnoszt z Pardubic. Arbitraż metropolity praskiego, związanego zarówno z jedną, jak i z drugą stroną konfliktu, okazał się być jednoznaczny i bezwzględny dla kanoników regularnych: nie otrzymali oni prawa do prowadzenia własnej szkoły (Korta, 1983, nr 551). Udział Arnoszta w sporze kłodzkich zgromadzeń zakonnych może budzić wiele emocji. Dość zastanawiający jest wyrok wydany w tej sprawie przez czeskiego dostojnika kościelnego. Bynajmniej nie mógł on zadowolić kanoników regularnych, których aklimatyzacja w Kłodzku i rozpoczęcie działalności na wielu płaszczyznach przebiegały pomyślnie pod czujnym i łaskawym okiem Arnoszta z Pardubic. Wydawać by się mogło, że związanemu z jednym i drugim klasztorem, rozdartemu między nimi arcybiskupowi trudno będzie podjąć taką decyzję, by zażegnać konflikt, sprawiedliwie traktując zwaśnione strony. Tymczasem arbitraż Arnoszta był niewątpliwie jednostronny, korzystny dla joannitów. Na decyzję duchownego wpłynęły zapewne dwa czynniki: fakt, że sam kształcił się w szkole prowadzonej przez szpitalników oraz cudowna wizja maryjna, której doświadczył w sąsiednim kościele parafialnym.

Arnoszt z Pardubic zmarł w 1364 roku w Rudnicach nad Łabą. Uroczystości pogrzebowe odbyły się w Pradze, zaś szczątki zmarłego spoczęły, zgodnie z jego wolą wyrażoną w testamencie (Korta, 1983, nr 986), w budowanym od niedawna gotyckim kościele farnym w Kłodzku, któ- 
rego był fundatorem. Dlaczego Arnoszt z Pardubic na miejsce swojego pochówku nie wybrał kościoła kanoników regularnych, należącego do zakonników działających w jego ulubionej kanonii? Otóż wedle tradycji arcybiskup praski miał zapowiedzieć rychłą przemianę kościoła zakonników żyjących zgodnie z regułą św. Augustyna na stajnię dla koni, w związku z czym nie chciał spocząć w miejscu, które miało ulec profanacji. Prorocza przepowiedź ziściła się w 1622 roku, gdy w czasie wojny trzydziestoletniej oblężony klasztor i kościół kanoników regularnych zostały przeznaczone na stajnie dla koni, a następnie zniszczone (Gröger, Sikorski, 1993, s. 16). Powyższą historię należy jednak traktować jako miejscową legendę, pewien element lokalnej pamięci o Arnoszcie. Arcybiskup zapewne chciał być pochowany w kłodzkiej farze ze względu na cudowne widzenie maryjne, które mu się przytrafiło dokładnie w tym miejscu.

Ciało czeskiego duchownego, zgodnie ze średniowiecznym zwyczajem, pochowane zostało pośrodku nawy głównej świątyni (naprzeciw ołtarza głównego), w komorze grobowej. Nad nią postawiono prostą, wykonaną z czerwonego marmuru tumbę. Na płycie wierzchniej pojawiła się figura zmarłego. Rzeźba, o nieco ponadnaturalnej wielkości, wykonana została z białego wapienia. Ustawiono ją w pozycji stojąco-leżącej. Głowa metropolity praskiego, nakryta bogato zdobioną mitrą, spoczywała na dwóch ułożonych poduszkach, natomiast stopy wspierały się o lwa, przy którym widniała tarcza z herbem rodowym Arnoszta z Pardubic. Prawą ręką arcybiskup błogosławił, zaś w lewej trzymał pastorał.

Trudno określić dokładnie, kiedy powstawał pomnik nagrobny Arnoszta z Pardubic, choć zdaniem Bogusława Czechowicza dzieło tworzono w latach 1370-1375 (Czechowicz, 1997, s. 179). Znaczniej więcej wiadomo o kulisach finansowania nagrobka, a także o warsztacie, w którym miał powstać. Pieniądze na ten cel wyłożyli kłodzcy joannici i najbliższa rodzina zmarłego, zaś wykonanie dzieła zlecił praskiej pracowni Piotra Parlera cesarz Karol IV (Zrůbek, 1985, s. 33).

Niejasne pozostają też okoliczności postępującego na przestrzeni wieków niszczenia gotyckiego nagrobka. Rzeźba do pewnego momentu świeciła pełnym blaskiem, zachwycając nie tylko miejscową ludność, ale też przybyszów z różnych stron świata, którzy odwiedzali kłodzki kościół parafialny, by pomodlić się w intencji wielkiego duchownego. Jakie były przyczyny uszkodzenia pomnika? W polskiej historiografii do dziś ich nie wyjaśniono, choć przyjmuje się, że zniszczeń dokonano ręką ludzką. Zgoła sprzeczna z tym poglądem jest kolejna z przepowiedni Arnoszta, podług której nagrobek miał zostać tajemniczo uszkodzony bez ingerencji człowieka (Gröger, Sikorski, 1993, s. 16).

Ulegająca stopniowej destrukcji gotycka płyta nagrobna nie została odnowiona do dziś. W XIX wieku przeniesiono ją do nawy bocznej kłodzkiego kościoła parafialnego, natomiast jej miejsce zajęło kenotafium metropolity praskiego, wykonane w 1870 roku. Posąg przedstawia klęczącego w szatach pontyfikalnych (z insygniami władzy arcybiskupiej) Arnoszta. Dłonie, w których trzyma pastorał, ułożone są w geście modlitewnym, kolana zaś oparte na wielkiej poduszce ozdobionej wizerunkiem czeskich lwów, trzymających w łapach herb rodowy Arnoszta $z$ Pardubic. Posąg, umieszczony na cokole $e^{4}$, jest ustawiony przodem do figurki Matki Boskiej

\footnotetext{
4 Brzegi cokołu opatrzone zostały następującą inskrypcją: ARNESTVS DE PARDVBICZ PRIMVS ARCHIEPISCOPVS PRAGENSIS NAT[VS] MCCLXXXXVII D[IE] XXV MARTII OBIIT A[NNO] D[OMINI] MCCCLXIIII D[IE] XXX M[ENSIS] IVNII.
} 
ulokowanej w ołtarzu głównym, dzięki czemu można odnieść wrażenie kontaktu wzrokowego pomiędzy rzeźbami. Postać wielkiego hierarchy kościelnego wydaje się być zadowolona z tego faktu, czego wyrazem jest lekki uśmiech na jego twarzy.

Dzieło wykonane zostało w marmurze kararyjskim przez górnośląskiego rzeźbiarza, związanego z berlińskim środowiskiem artystycznym, Jana Jandę. Za pomysłodawcę stworzenia nowego pomnika uznaje się śląskiego starożytnika, hrabiego Rudolfa Stillfrieda-Rattonitza, natomiast donatorami przedsięwzięcia byli m.in. kardynał arcybiskup praski Friedrich Josef von Schwarzenberg oraz cesarzowa austriacka Elżbieta Bawarska (Czechowicz, 2008, s. 123).

Postać Arnoszta z Pardubic upamiętniana była przez kłodzką społeczność nie tylko za sprawą imponujących artystycznie pomników nagrobnych. Metropolita praski odgrywał również niepoślednią rolę w miejscowym dziejopisarstwie. Na przestrzeni kilkunastu lat po śmierci doczekał się aż trzech wersji swojego żywota. Za autora najwcześniejszej uważa się Wilhelma z Lestkowa, dziekana kapituły wyszehradzkiej i bliskiego współpracownika Arnoszta z Pardubic. Dzieło dobrze przygotowanego do pracy historyczno-literackiej duchownego (Mrozowicz, 1998b, s. 27) ma charakter utworu zarówno historiograficznego, jak i hagiograficznego (Mrozowicz, 2008, s. 31-41). Nietrudno dostrzec w nim kilka ciekawych szczegółów biograficznych z życia pierwszego metropolity praskiego. Wilhelm opisał m.in. środowisko rodzinne Arnoszta, wspominając o roli, jaką odgrywał jego ojciec w Kłodzku, lata nauki w szkole joannitów oraz na uczelniach włoskich, objęcie godności arcybiskupa Pragi, działalność fundacyjną Pardubiczanina, wzmiankując przy tym o założeniu klasztoru kanoników regularnych w Kłodzku, a także o momencie jego śmierci. We fragmentach tych pojawiają się nazwy miejscowe i osobowe oraz daty - elementy typowe dla tekstu historiograficznego. Jednakowoż nie brak w biografii metropolity praskiego cech utworu hagiograficznego. Wilhelm z Lestkowa znacznie więcej miejsca w swym dziele poświęcił na ukazanie bogobojności i postawy moralnej Arnoszta z Pardubic. Z żywota dowiedzieć się można m.in. o szczodrości, skromności i wielkiej pokorze metropolity praskiego. Wilhelm przedstawił Arnoszta jako godnego naśladowania człowieka i duchownego, który winien być kanonizowany. Do dziełka kanonika wyszehradzkiego dołączony został także opis wspomnianej, cudownej wizji maryjnej (sporządzony przez arcybiskupa), do której doszło w Kłodzku. Nie ulega zatem wątpliwości, że omawiana wersja biografii metropolity praskiego ma również hagiograficzny charakter. Utwór nie powstał zapewne w Kłodzku, ale okazał się swoistym impulsem dla kłodzkiego duchowieństwa do podjęcia pracy nad kolejną wersją żywota Arnoszta z Pardubic. Druga redakcja, będąca przeróbką dzieła Wilhelma (Mrozowicz, 2008, s. 32-33), wyszła ze skryptorium klasztoru kanoników regularnych spod pióra Jana Kłodzkiego, pierwszego prepozyta miejscowej kanonii. Jan, podobnie jak Wilhelm, również posiadał kompetencje pisarskie, był bowiem autorem komentarzy do listów św. Pawła do Rzymian i Koryntian (Mrozowicz, 1998a, s. 411-412). Redakcja Jana Kłodzkiego stanowiła cenne źródło historyczne dla Michała Czacheritza, XV-wiecznego prepozyta klasztoru kanoników regularnych w Kłodzku, podczas sporządzania przezeń kroniki tutejszej kanonii.

Celem kroniki było przede wszystkim zaprezentowanie dziejów klasztoru kłodzkiego od momentu jego założenia po czasy współczesne autorom (Mrozowicz, 2001, s. 95), niemniej jednak w dziele nie brakuje też fragmentów poświęconych Arnosztowi z Pardubic. Tuż po prologu następują dwa rozdziały poświęcone metropolicie praskiemu. W pierwszym znajduje się żywot 
Arnoszta (najpewniej wspomniana wersja pióra Jana Kłodzkiego), natomiast drugi przybliża okoliczności fundacji kłodzkiego konwentu (Kronika, 2003, s. 2-5). Dalej przeczytać można o wydarzeniach niezawartych w średniowiecznym żywocie czeskiego dostojnika kościelnego. Uwagę przykuwa opis cudu związanego z palcem św. Mikołaja. Miraculum polegało na tym, że dzięki gorliwej modlitwie Arnoszta krwawiący palec św. Mikołaja, podzielony wcześniej na dwie części przez cesarza Karola IV (miał trafić do dwóch różnych kościołów w formie relikwii), został ponownie scalony (Kronika, 2003, s. 223). W innym miejscu można znaleźć ciekawy fragment o dwukrotnym wycieku oleistej cieczy z nagrobka Arnoszta w 1468 roku. Tajemniczy balsam prepozyt Michał Czacheritz określił mianem wody łez, która miała być symbolem płaczu mieszkańców Kłodzka z racji nadchodzących szkód i nieszczęść (Kronika, 2003, s. 202). W kronice umieszczony jest też list Michała adresowany do legata papieskiego Rudolfa z Rüdesheim, z którego dowiedzieć się można o kilku interesujących faktach, dotyczących zadziwiającej emanacji olejku z nagrobka Arnoszta. Jak się okazało, próbkę tajemniczego płynu do przebywającego we Wrocławiu legata wysłali kłodzcy joannici, zaś Czacheritz do wspomnianego listu dołączył żywot arcybiskupa praskiego wraz z opisem wizji maryjnej (Kronika, 2003, s. 203-204). Działania joannitów i prepozyta kanonii miały motyw natury religijno-politycznej - duchowni liczyli, że legat wycofa interdykt ciążący na mieście, który nałożył rok wcześniej. Niemniej jednak, być może, były to pierwsze, śmiałe próby udowodnienia, że Arnoszt z Pardubic zasługuje na miano świętego.

Na marginesie powyższych wywodów, ciekawostką pozostaje fakt, że Michał Czacheritz, współautor kroniki, opisując początki kanonii i osobę jej założyciela, opierał się na rękopisie żywota, który powstawał właściwie w tym samym skryptorium co kronika. Stworzenie tego ważnego utworu literackiego sprawiło, że pamięć o arcybiskupie praskim ożywiła się w Kłodzku.

Joannici i kanonicy regularni św. Augustyna to nie jedyne zakony, które przeróżnymi działaniami upamiętniały Arnoszta z Pardubic i jego powiązania z Kłodzkiem. U schyłku XVI stulecia do największego ośrodka Ziemi Kłodzkiej przybyli jezuici, którzy dość szybko uświadomili sobie, że znaczenie Arnoszta jest w mieście duże i może okazać się wielce przydatne w kontekście działań kontrreformacyjnych. Odwoływanie się do średniowiecznych autorytetów było swego rodzaju specjalnością Towarzystwa Jezusowego, toteż nie może dziwić fakt, że losy wielkiego hierarchy kościelnego opisał w swej pracy czeski historyk, uczeń i nauczyciel w kłodzkim kolegium jezuickim, Bogusław Alojzy Balbin (Balbinus, 1664). Dzieło jezuity wydane zostało w 1664 roku, czyli dokładnie w trzechsetlecie śmierci Arnoszta z Pardubic. Cennym elementem książki Balbina jest bogaty materiał ikonograficzny, na który składają się miedzioryty. Dwie grafiki przedstawiają Arnoszta czczącego Matkę Boską: na jednej zaprezentowana jest cudowna wizja młodzieńca, natomiast na drugiej widać adorującego Madonnę arcybiskupa. Uwagę przykuwa także miedzioryt ukazujący jednocześnie rekonstrukcję nagrobka dostojnika kościelnego oraz widok tegoż pomnika w stadium rozpadu. Dzięki Balbinowi można zobaczyć, jak bardzo posąg został zniszczony w drugiej połowie XVII stulecia i jak świetnie wyglądał przed dewastacją. Podobne grafiki można znaleźć również w dziele Jana Millera, rektora kłodzkiego kolegium jezuickiego, wydanym w 1690 roku (Miller, 1690).

Współcześnie tradycja Arnoszta z Pardubic wciąż odgrywa istotną rolę w kulturze Kłodzka. Zainteresowanie czeskim duchownym wzrosło na początku XXI wieku za sprawą 640. rocznicy 
jego śmierci. W latach 2003-2005 w ramach obchodów tego jubileuszu odbyło się wiele rozmaitych wydarzeń, organizowanych przez Muzeum Ziemi Kłodzkiej i Muzeum Wschodnioczeskie w Pardubicach. Na pierwszy plan wysuwa się międzynarodowa konferencja naukowa poświęcona Arnosztowi, która odbyła się 22-24 września 2004 roku. Jej owocem była praca zbiorowa, zawierająca sporo interesujących referatów (Bobková, Gładkiewicz, Vorel, 2005). W tym samym roku wydana została pierwsza popularnonaukowa biografia w języku polskim autorstwa Zdzisława Szczepaniaka (Szczepaniak 2004), a także odbyła się uroczystość nadania auli w kłodzkim I Liceum Ogólnokształcącym (dawny gmach kolegium jezuickiego) imienia Arnoszta z Pardubic. Uzupełnieniem wspomnianej konferencji było, zorganizowane 11 kwietnia 2005 roku, międzynarodowe sympozjum dotyczące Arnoszta i jego spuścizny w Ziemi Kłodzkiej. Pokłosiem tego spotkania była kolejna polsko-czeska praca zbiorowa (Gładkiewicz, Šebek, 2005). Warto też dodać, że w pierwszej dekadzie XXI wieku na język polski przetłumaczone zostały, dzięki zaangażowaniu Muzeum Ziemi Kłodzkiej, dwa cenne źródła poświęcone Arnosztowi - wspomniany już utwór Wilhelma z Lestkowa oraz wczesnonowożytna biografia arcybiskupa praskiego (oparta na wersji żywota Jana Kłodzkiego), napisana przez Walentego Krautwalda (Walenty Krautwald, 2009), śląskiego bibliofila, humanistę, autora dzieł teologicznych i bliskiego współpracownika biskupa wrocławskiego, Jana Turzona ${ }^{5}$.

Arnoszt z Pardubic to nie jedyna postać historyczna, wobec której kłodzka społeczność podejmuje zabiegi komemoratywne. Z miastem związany jest m.in. św. Melchior Grodziecki, żyjący w XVI i XVII wieku polski jezuita i męczennik (Szczepaniak, 2007), którego imieniem nazwana została sala tradycji i historii szkoły we wspomnianym wcześniej liceum. Kolejnym upamiętnionym w Kłodzku duchownym jest bł. Gerhard Hirschfelder, niemiecki duchowny katolicki, ofiara obozu koncentracyjnego w Dachau (Szczepaniak, 2010). W 2011 roku wschodnia część ulicy Ignacego Łukasiewicza, znajdująca się w pobliżu kościoła parafialnego w Kłodzku, została przemianowana na ulicę Błogosławionego Księdza Gerharda Hirschfeldera. Wyżej wymienionym świątobliwym bohaterom lokalnej historii poświęcone zostały także książki biograficzne, wydane w Kłodzku, których autorem był Szczepaniak. Nie ulega zatem wątpliwości, że lokalna społeczność stara się ocalić tych dwóch duchownych od zapomnienia, niemniej jednak nie w takim stopniu, jak w przypadku działań mających na celu upamiętnienie postaci Arnoszta z Pardubic, co świadczy o wyjątkowości tych zabiegów. Ze względu na swoją doniosłą działalność donacyjną arcybiskup praski niezwykle zasłużył się współczesnym mu mieszkańcom Kłodzka. W mieście wytworzyła się świadomość historyczna, która z czasem przekształciła się w działania mające na celu upamiętnienie postaci czeskiego duchownego. Kłodzczanie na kartach swych dzieł literackich poświęcali sporo miejsca życiu i czynom arcybiskupa praskiego (żywot Jana Kłodzkiego, fragmenty kroniki klasztoru kanoników regularnych, dzieło Bogusława Alojzego Balbina, współczesna książka Szczepaniaka), zaś w XIX wieku w miejscowym kościele parafialnym stanęło wspomniane, przepiękne kenotafium czeskiego dostojnika kościelnego.

Szereg zróżnicowanych zdarzeń, występujących na przestrzeni wielu stuleci, dobitnie pokazuje, w jakim stopniu dba się w Kłodzku o historię „małej ojczyzny”. Przykład Arnoszta z Pardubic dobrze ilustruje pielęgnowanie pamięci lokalnej poprzez upamiętnianie $\mathrm{w}$ ramach in-

\footnotetext{
5 Więcej o Krautwaldzie: Mrozowicz, 2005, s. 75-76.
} 
stytucji (muzeum, szkoła, kościół) oraz zaangażowania pojedynczych osób (w tym wypadku historyków piszących o czeskim dostojniku kościelnym). Działania kłodzkiej społeczności wpisują się również w model pamięci lokalnej, w której centrum znajdują się wybrane, wybitne jednostki. Tak jest z Arnosztem, obecnym na kartach wielu opracowań dotyczących historii Ziemi Kłodzkiej. Da się także zauważyć, że pamięć lokalna o pierwszym arcybiskupie praskim ma charakter uniwersalny - początkowo czczony tylko przez czeskich mieszkańców Kłodzka, z czasem stał się bohaterem historycznym nieobojętnym dla niemieckojęzycznej społeczności przebywającej w największym ośrodku Ziemi Kłodzkiej (pomysł wybudowania nowego pomnika nagrobnego w XIX wieku). Od jakiegoś czasu Arnoszt z Pardubic jest również istotną postacią dla Polaków zamieszkujących Kłodzko, którzy za sprawą różnorodnych inicjatyw starają się pielęgnować lokalną pamięć o metropolicie Pragi. Ta wspólna wielowiekowa tradycja, oparta w tym przypadku na pielęgnowaniu pamięci o bohaterze regionalnym, jest czynnikiem, który decyduje o istnieniu tożsamości regionalnej na Ziemi Kłodzkiej6.

\section{Bibliografia podmiotowa}

Balbinus, B. (1664). Vita venerabilis Arnesti (vulgo Ernesti) primi archiepiscopi Pragensis... Pragae: Excudebat Pragae, in Archiepiscopali Typographia apud S. Benedictum in Collegio S. Norbeti, Adamus Kastner. Korta, W. (red.) (1983). Regesty ślaskie. T. 2: 1349-1355. Wrocław: Zakład Narodowy im. Ossolińskich.

Kronika klasztoru kanoników regularnych (św. Augustyna) w Kłodzku (2003). Wyd. W. Mrozowicz. Wrocław: Centrum Badań Śląskoznawczych i Bohemistycznych Uniwersytetu Wrocławskiego.

Krautwald, W. (2009). Żywot Arnošta z Pardubic według Walentego Krautwalda. Przekł. A. Misiaszek, wstęp i przyp. Z. Szczepaniak. Kłodzko: Muzeum Ziemi Kłodzkiej.

Miller, J. (1690). Historia Beatissimae Virginis Glacensis. Das ist kurtze Beschreibung von dem uralten wunderthätigen Mariabild. Glatz: Andreas Franz Pega.

Wilhelm z Lestkowa (2004). Żywot czcigodnego Arnošta - pierwszego arcybiskupa kościoła praskiego. Przekł. A. Misiaszek, oprac. tekstu i przyp. Z. Szczepaniak. Nowa Ruda: [Wydawca nieznany].

\section{Bibliografia przedmiotowa}

Assmann, A. (2013). Między historiq a pamięcią. Antologia. Red. nauk. i posł. M. Saryusz-Wolska. Warszawa: Wydawnictwo Uniwersytetu Warszawskiego.

Broniewski, T. (1970). Kłodzko. Wyd. 2. uzup. Wrocław: Zakład Narodowy im. Ossolińskich.

Connerton, P. (2012). Jak społeczeństwa pamiętają. Przekł. i wstęp M. Napiórkowski. Warszawa: Wydawnictwo Uniwersytetu Warszawskiego.

Czechowicz, B. (1997). Nagrobek i historiografia. O niektórych treściach i funkcjach kłodzkich pomników nagrobnych z XIV-XIX wieku. W: B. Czechowicz, A. Dobrzyniecki (red.), O sztuce sepulkralnej na Śla-

6 O innych czynnikach (w kontekście Śląska) zob. Mrozowicz, 2012, s. 139-161. 
sku. Materiały z sesji Oddziału Wrocławskiego Stowarzyszenia Historyków Sztuki, 25-26 października 1996 roku (s. 177-202). Wrocław: Stowarzyszenie Historyków Sztuki.

Czechowicz, B. (2008). Arnošt z Pardubic a dylematy czeskiej świadomości historycznej w XIX wieku. Interpretacyjne problemy z kłodzkim pomnikiem arcybiskupa z 1870 r. W: R. Gładkiewicz, F. Šebek (red.), Tradycja Arnošta z Pardubic w kulturze Ziemi Kłodzkiej (s. 119-128). Wrocław-Pardubice: Dolnośląska Biblioteka Publiczna im. T. Mikulskiego. Východočeské Muzeum.

Dziewulski, W. (1957). Kłodzko w XIV i początkach XV wieku (ze szkicem sytuacyjnym). Śląski Kwartalnik Historyczny Sobótka, 12 (3), 447-485.

Gębarowicz, M. (1965). „Psałterz Floriański” i jego geneza. Wrocław: Zakład Narodowy im. Ossolińskich.

Gröger, R., Sikorski, M. (1993). Na granicy legendy i wiary. Skarby sztuki i osobliwości Ziemi Kłodzkiej. Nowa Ruda: Wydawnictwo „Ziemia Kłodzka”.

Halbwachs, M. (2008). Społeczne ramy pamięci. Tłum. M. Król. Warszawa: Wydawnictwo Naukowe PWN. Le Goff, J. (2007). Historia i pamięć. Przekł. A. Gronowska, J. Stryjczyk. Warszawa: Wydawnictwo Uniwersytetu Warszawskiego.

Łatak, K. (1999). Kanonicy regularni laterańscy na Kazimierzu w Krakowie do końca XVI wieku. Ełk: Kuria Biskupia Diecezji Ełckiej.

Matusik, L. (1965). Niektóre aspekty dziejów klasztoru kanoników regularnych w Kłodzku a zagadnienie „Psałterza Floriańskiego”. Ślaski Kwartalnik Historyczny Sobótka, 20 (3), 277-317.

Mikołajczak, T. (2008). Stan badań nad nagrobkiem Arnošta w kłodzkim kościele Wniebowzięcia Najświętszej Marii Panny. W: R. Gładkiewicz, F. Šebek (red.), Tradycja Arnošta z Pardubic w kulturze Ziemi Kłodzkiej (s. 83-89). Wrocław-Pardubice: Dolnośląska Biblioteka Publiczna im. T. Mikulskiego. Východočeské Muzeum.

Mrozowicz, W. (1995). Szkoła klasztoru kanoników regularnych-augustianów w Kłodzku w średniowieczu. W: A. Pobóg-Lenartowicz, M. Derwich (red.), Klasztor w kulturze średniowiecznej Polski. Materiały z ogólnopolskiej konferencji naukowej zorganizowanej w Dąbrowie Niemodlińskiej w dniach 4-6 XI 1993 przez Instytut Historii WSP w Opolu i Instytut Historyczny Uniwersytetu Wrocławskiego (s. 63-81). Opole: Wydawnictwo Św. Krzyża.

Mrozowicz, W. (1998a). Kanonicy regularni św. Augustyna (augustianie) na Śląsku. Śląski Kwartalnik Historyczny Sobótka, 53 (3-4), 401-413.

Mrozowicz, W. (1998b). Ze studiów nad tradycją rękopiśmienną żywota arcybiskupa praskiego Ernesta z Pardubic. Śląski Kwartalnik Historyczny Sobótka, 53 (1-2), 19-32.

Mrozowicz, W. (2000). Klęski żywiołowe w ziemi kłodzkiej w średniowieczu. W: W. Iwańczak, K. Bracha (red.), Człowiek i przyroda w średniowieczu i we wczesnym okresie nowożytnym (s. 209-226). Warszawa: Wydawnictwo DiG.

Mrozowicz, W. (2001). Kronika klasztoru kanoników regularnych w Kłodzku. Ze studiów nad średniowiecznym dziejopisarstwem klasztornym. Wrocław: Wydawnictwo Uniwersytetu Wrocławskiego.

Mrozowicz, W. (2005). Krautwald Walenty. W: J. Lyszczyna, D. Rott (red.), Słownik pisarzy ślaskich. T. 1 (s. 75-76). Katowice: Wydawnictwo Uniwersytetu Śląskiego.

Mrozowicz, W. (2008). Średniowieczne żywoty Arnošta z Pardubic. Między historiografią a hagiografią. W: R. Gładkiewicz, F. Šebek (red.), Tradycja Arnošta z Pardubic w kulturze Ziemi Kłodzkiej (s. 31-41). Wrocław-Pardubice: Dolnośląska Biblioteka Publiczna im. T. Mikulskiego. Východočeské Muzeum.

Mrozowicz, W. (2012). W poszukiwaniu śląskiej tożsamości regionalnej (do 1526 r.). Ślaski Kwartalnik Historyczny Sobótka, 67 (4), 139-161.

Nahirny, R. (2010). Pamięć lokalna na ziemi kłodzkiej po 1989 roku. Raport ze stanu badań. Kultura Wspótczesna, 18 (1), 139-147. 
Orłowski, J. (2005). Arnošt z Pardubic i czeski ruch devotio moderna. W: L. Bobková, R. Gładkiewicz, P. Vorel (red.), Arnošt z Pardubic (1297-1364). Postać - środowisko - dziedzictwo (s. 195-198). WrocławPraha-Pardubice: Centrum Badań Śląskoznawczych i Bohemistycznych Uniwersytetu Wrocławskiego.

Pobóg-Lenartowicz, A. (1999). Kanonicy regularni na Ślasku. Życie konwentów w śląskich klasztorach kanoników regularnych w średniowieczu. Opole: Wydawnictwo Uniwersytetu Opolskiego.

Poczykowski, R. (2010). Lokalny wymiar pamięci. Pamięć zbiorowa i jej przemiany w pótnocno-wschodniej Polsce. Białystok: Wydawnictwo Uniwersytetu w Białymstoku.

Staffa, M. (red.) (1994). Słownik geografii turystycznej Sudetów. T. 15: Kotlina Kłodzka. Wrocław: Wydawnictwo I-BIS.

Szczepaniak, Z. (2004). Arnošt z Pardubic. Kłodzko-Nowa Ruda: Wydawnictwo „Maria”.

Szczepaniak, Z. (2005). Kolegium jezuickie i konwikt w Kłodzku 1597-1945. Kłodzko: Wydawnictwo „Maria”. Szczepaniak, Z. (2007). Święty Melchior Grodziecki. Kłodzko: [Wydawca nieznany].

Szczepaniak, Z. (2010). Duszpasterz młodzieży. Ks. Gerhard Hirschfelder. 1907-1942. Kłodzko: Wydawnictwo „Maria”.

Szpociński, A. (red.) (2005). Wobec przeszłości. Pamięć przeszłości jako element kultury współczesnej. Warszawa: Instytut im. Adama Mickiewicza.

Woniak, K. (2014). Pamięć lokalna. W: M. Saryusz-Wolska, R. Traba (red.), Modi memorandi. Leksykon kultury pamięci (s. 339-440). Warszawa: Wydawnictwo Naukowe Scholar.

Zrůbek, R. (1985). Kłodzki nagrobek Arnoszta z Pardubic. Tłum. K. Toczyńska-Rudysz. Zeszyty Muzeum Ziemi Kłodzkiej, 1, 33-38.

\section{Arnošt of Pardubice in the local memory of Kłodzko}

Summary

The article discusses the role of Arnošt of Pardubice in local memory of the region of Kłodzko. Arnošt, the first Prague archbishop and the nearest associate of Holy Roman Emperor Charles IV, was closely connected with the capital of the province. His resilient activity here (founding of churches, establishing of the monastery of Canons Regular St. Augustine) gave him the status of a significant local historical figure. Arnošt's remains rest in the parish church in Kłodzko to date and the local community take care of commemorating him by organizing various initiatives. These initiatives show the identification and attachment to the region.

Słowa kluczowe: pamięć lokalna, historia lokalna, Arnoszt z Pardubic, arcybiskup praski, Kłodzko, upamiętnienie, tożsamość regionalna

Keywords: local memory, local history, Arnošt of Pardubice, Archbishop of Prague, Kłodzko, commemoration, regional identity 